\title{
Submerged macrophyte zonation in a Mediterranean salt marsh: a facilitation effect from established helophytes?
}

\author{
Espinar, J.L. ${ }^{*}$; García, L.V. ${ }^{1}$; García Murillo, P. ${ }^{2}$ \& Toja, J.2 \\ ${ }^{1}$ Departamento de Geoecología, Instituto de Recursos Naturales y Agrobiología de Sevilla \\ (CSIC), P.O. Box 1052, E-41080 Sevilla, Spain; ${ }^{2}$ Departamento de Biología Vegetal y Ecología, Universidad de Sevilla, \\ A.P. 1095, E-41080 Sevilla, Spain; *Corresponding author; E- mail jlespinar@irnase.csic.es; Fax +34 954624002
}

\begin{abstract}
The relationship between communities of submerged annual macrophytes (predominately Chara spp.) and environmental characteristics is studied in three habitats with different dominant perennial species (Arthrocnemum, Juncus, Scirpus) and areas of bare soil. The distribution of submerged annual macrophytes is significantly dependent on two independent environmental factors: a dominant gradient of flooding/salinity, and a secondary gradient of nutrients related exclusively to the combined abundance of helophytes of the genus Scirpus (S. maritimus and $S$. litoralis). The results suggest that these emergent helophytes (1) are able to modify water column parameters (such as concentration of nitrates, phosphates, potassium, and bicarbonates) which are important for the communities of submerged macrophytes, and (2) play a fundamental role in the generation of secondary sources of environmental variability which, superimposed on the main gradient of flooding/salinity, favours the appearance of new compositional equilibria in such communities.

The existence of a process of facilitation is discussed by which the emergent helophytes induce changes in nutrient availability that would favour relatively nutrient-demanding charophyte species (such as Chara connivens and Nitella hyalina), altering the established relationships with other coexisting charophytes (such as Chara canescens and $C$. galioides) that dominate in the absence of the facilitating species. Nevertheless, the increased nutrient concentration associated to the presence of helophytes would not introduce significant changes in the total biomass of submerged aquatic macrophytes.
\end{abstract}

Keywords: Biotic factor; Charophyte; DCCA; Doñana; Nutrient; RDA; Resource gradient.

Nomenclature: Valdés et al. (1987); Corillion (1961) for Charophytes.

Abbreviations: $\mathrm{SBM}=$ Seasonal biomass maximum; $\mathrm{SOM}=$ Soil organic matter; STN $=$ Total nitrogen; STP $=$ Total phosphorus.

\section{Introduction}

Marshes of submerged aquatic macrophytes, comprising diverse species of chlorophyte macro-algae (Characeae) and spermatophytes (Ruppiaceae and Zannichelliaceae), are responsible for much of the primary production of salt marshes under Mediterranean climate (van Vierssen 1982), intervene in a great number of physico-chemical and metabolic processes in the water column (Carpenter \& Lodge 1986), and are determinant elements in nutrient cycles in Mediterranean wetlands (Golterman 1995). Submerged annual macrophytes often coexist seasonally with populations of emergent helophytes (Scirpus, Juncus, Eleocharis) and with woody Chenopodiaceae (Arthrocnemum, Sarcocornia) (Rivas Martínez et al. 1980; Podlejski 1981; García et al. 1993). Some of these perennial species develop dense networks of rhizomes and roots that can alter the physico-chemical characteristics of the sediment, at the same time contributing great amounts of senescent shoots to the soil surface at the end of each growing season (Jaynes \& Carpenter 1986; Chen \& Barko 1988).

The irregularity of the flooding period, and the variations in salinity, have been recognized as the main factors determining the composition of plant communities - both terrestrial (García et al. 1993) and aquatic (Grillas 1990; Grillas et al. 1993a) - in the temporary marshes under Mediterranean climate. In these annual communities are established from an abundant and diverse seed bank, capable of generating a great number of species depending on the dominant environmental conditions in a particular hydrological cycle (Grillas et al. 1993a; Marañón 1998).

However, the importance of biotic interactions is increasingly taken into account in the structuring of plant communities in littoral saline habitats (Ungar 1998; Noe \& Zedler 2001). Intra- and interspecific interactions, both negative (e.g. competition) and positive (e.g. facilitation), can operate simultaneously, the result depending on factors such as life stage, plant density, species-specific physiology, indirect interactions, or bi- 
otic stress (Callaway \& Walker 1997; Chambers 2001). In areas of marked environmental stress (i.e. Mediterranean salt marshes), facilitation mechanisms have a decisive role in species distribution and the zonation of plant communities (Bertness \& Callaway 1994; Callaway 1994; Rubio-Casal et al. 2001). Despite the significance of positive interactions as they have been documented for different habitats and zones, the processes of facilitation in communities of submerged aquatic plants are little documented at a worldwide scale (Callaway \& Walker 1997; Ungar 1998).

The aim of this work is (1) to study the main trends of variation of the variables (water and sediment) in aquatic environments of the marsh in Doñana National Park; (2) to identify the environmental factors which are significantly related to the distribution of submerged annual macrophytes; (3) to detect possible influences of the perennial species on the distribution and production of the submerged annual communities.

\section{Methods}

Study site

The study area comprises ca. 6000 ha of marshland in the Doñana National Park, situated south of the Guadalquivir estuary (SW Spain). The marsh is practically isolated from tidal influence, but the lower zones are subject to seasonal flooding (5-8 months a year) under influence of precipitation and storm discharge of some streams, and behave as a floodplain. The substrate consists of silty-clayey, calcareous, saline sediments (Clemente et al. 1998). Small differences (a few dm) in elevation result in differences in the length of the period of flooding. There is a marked seasonality in water availability, with a clear differentiation between a dry season (June-October) and a wet one (November-April).

The vegetation of the marsh has been described by Rivas Martínez et al. (1980), and its relationships with the environmental variables by Marañón et al. (1989) and García et al. (1993). It comprises perennial forma- tions of woody Chenopodiaceae and emergent helophytes. Depending on the duration of flooding, communities of annual grasses (García et al. 1993; Marañón, 1998) or submerged aquatic macrophytes (GarcíaMurillo et al. 1990; Espinar et al. 1997) establish in the perennial vegetation.

\section{Plant analysis}

Plants were sampled during the spring of 1997, in a wet period ( $803 \mathrm{~mm}$ precipitation from from September 1996-August 1997 and $850 \mathrm{~mm}$ in the 12 months

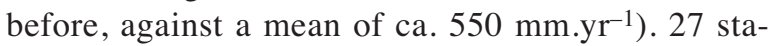
tions were distributed randomly in three habitats, differentiated by their physiographic position and dominant perennial community:

1. Lucios (bare soil, in lower marsh), without any perennial cover;

2. Pajas ('Scirpus community', in lower marsh), dominated by Scirpus maritimus and S. litoralis;

3. Quebradas (Arthrocnemum-Juncus community in the transition to upper marsh), dominated by Arthrocnemum macrostachyum and Juncus subulatus (Table 1).

Each station was monitored weekly to detect the seasonal biomass maximum (SBM; Wetzel 1981) of the submerged macrophyte communities. The abundance of emergent perennial species and of bare soil was estimated in plots of $10 \mathrm{~m}^{2}$. Within each plot a square of $0.5 \mathrm{~m} \times 0.5 \mathrm{~m}$ was situated at random, in which all above-ground and below-ground biomass from submerged aquatic macrophytes was collected, and the perennial cover recorded. For each species, dry biomass was determined (after $72 \mathrm{~h}$ at $80{ }^{\circ} \mathrm{C}$ ). The term submerged macrophyte was extended to include Ranunculus peltatus ssp. fucoides and Damasonium alisma.

\section{Environmental analysis}

In each site, the total duration of the flooding period (FloodT, in wk) was estimated by weekly monitoring. At the time SBM was reached, the depth ('Wdepth'), transparency ('Disk'), $\mathrm{pH}$, and electrical conductivity (EC) of the water were determined in situ, and the

Table 1. Selected habitats for sampling submerged macrophytes. Local name, physiographical position, dominant perennial species, average flooding regime, percent of the total flooded area accounted for, and number of samples in each habitat are indicated.

\begin{tabular}{|c|c|c|c|}
\hline & Arthrocnemum-Juncus & $\begin{array}{l}\text { Habitat } \\
\text { Bare soil }\end{array}$ & Scirpus \\
\hline Local name & 'Quebradas' & 'Lucios’ & 'Pajas' \\
\hline Physiographical unit & Transition to upper marsh & Lower marsh & Lower marsh \\
\hline Established vegetation & Arthrocnemun macrostachyum, Juncus subulatus & No perennials & Scirpus maritimus, Scirpus litoralis \\
\hline Average flooding & Medium & Long & Long \\
\hline$\%$ flooded area & 45 & 20 & 35 \\
\hline No. of sample sites & 13 & 6 & 8 \\
\hline
\end{tabular}


content in carbonates and bicarbonates in one sample was measured immediately by titration with sulphuric acid.

The concentration of chlorophyll-a was estimated by filtration of 0.51 water and later extraction with methanol (at $4{ }^{\circ} \mathrm{C}$, in darkness, for $24 \mathrm{~h}$; Talling \& Driver 1963). The filtered water was stored with a few drops of chloroform at $4{ }^{\circ} \mathrm{C}$ before laboratory analyses were done of the contents of soluble reactive $\mathrm{P}$ (Murphy \& Ripley 1963), nitrate (phenoldisulfonic acid), Ca and $\mathrm{Mg}$ (AAS), and $\mathrm{Na}$ and $\mathrm{K}$ (flame photometry).

At three points inside each sampling station, random samples were taken of the upper $5 \mathrm{~cm}$ of sediment. These were mixed and homogenized after removal of plant remains present at the surface to constitute a single sample. The samples were air-dried, ground and sieved to $2 \mathrm{~mm}$. In each of them we determined soil organic matter (SOM, ashing at $450{ }^{\circ} \mathrm{C}$ for $4.5 \mathrm{~h}$ ), total nitrogen (STN, acid digestion with $\mathrm{K}_{2} \mathrm{~S}_{2} \mathrm{O}_{8}$ and determination of the resulting ammonia), and total phosphorus (STP, acid digestion with $\mathrm{K}_{2} \mathrm{~S}_{2} \mathrm{O}_{8}$ and determination of the resulting soluble phosphorus). All water and sediment analyses were performed according to standard procedures (APHA; Anon. 1985).

\section{Data analysis}

Multivariate data analyses were performed to explore the underlying structures in species and environmental data, based on linear or unimodal models of relationship, depending on prior analysis of the diagrams of dispersion between variable pairs and on the length of the gradients detected (Jongman et al. 1997).

Principal Component Analysis (PCA) and Redundancy Analysis (RA) based on a linear model, were found appropriate to analyse the set of environmental variables and their relationships with the abundance values of the perennial species, while Canonical Correspondence Analysis (CCA) and Detrended Canonical Correspondence Analysis (DCCA) based on a unimodal model, were more appropriate to describe the relationship between submerged macrophytes and environmental variables. The significant number of ordination axes was decided following the criterion of Kaiser (eigenvalues $>1$ ) in the case of PCA, and following the results of a Monte Carlo test in the case of the constrained ordinations (CCA and RA). In the canonical analyses, the best set of explanatory variables was selected by (1) ignoring variables with a high variance inflation factor (VIF > 20), and (2) forward selection and repeated Monte Carlo tests of the remaining set of variables.

The existence of significant multivariate differences in the floristic composition and environmental characteristics of the three habitats investigated was contrasted using the MRPP (Multi-Response Permutation Procedure) test (Zimmerman et al. 1985). When the null hypothesis of the MRPP test was rejected, univariate differences between the habitats were contrasted, using one-way ANOVA or, alternatively, the Kruskal-Wallis test when the requisite assumptions were not fulfilled. Post hoc comparisons were performed using the Newman-Keuls test or, alternatively, by between-habitat paired $U$-test comparisons. In all cases, an overall significance level of 5\% was fixed; the inflation of typeI error was avoided by applying a variant of the Bonferroni correction (Holm 1979). Nevertheless, redundant variables were not considered in Bonferroni- $P$ corrections to avoid unnecessary type-II error inflation.

\section{Results}

\section{Environmental variables}

Preliminary analysis of the 18 environmental variables sampled at the time of SBM showed that the requirements for PCA application - normality, linearity, and structured correlation matrix (sphericity test, $P<$ 0.0001, KMO Index $=0.7$ ) - were satisfied. PCA analysis produced five interpretable factors accounting for $83 \%$ of the total variance in the SBM environmental data set (Table 2). The first factor ('Salinity') was positively correlated $(0.8-0.9)$ with electrical conductivity and content of the main soluble ions in the water column. Factor 2 ('Ca-acidity') was positively correlated with the content of $\mathrm{Ca}$ and bicarbonate, and negatively correlated with $\mathrm{pH}$ and carbonate content of the water. Factor 3 ('Nutrients') was significantly and positively correlated with the content of the main limiting nutrients in water (nitrate and phosphate) and soil (STN and SOM) and with the concentration of chlorophyll-a (Chla) in the water. Factor 4 ('Wdepth') was correlated with the depth and transparency of the water at SBM time. Factor 5 ('FSTP') was related only with the total phosphorus content in the sediment (Table 2).

The MRPP test detected highly significant multivariate differences $\left(P<2.10^{-6}\right)$ in the environmental characteristics of the three 'communities' studied (Scirpus community, Arthrocnemum-Juncus community and bare soil). The differences remained significant after excluding the duration of flooding $\left(P<5.10^{-5}\right)$ and the factors related to the physical characteristics (depth and transparency) of the water column at the seasonal biomass maximum $\left(P<10^{-3}\right)$. The multivariate differences between community pairs were highly significant $\left(P<5.10^{-}\right.$ ${ }^{4}$ in the three comparisons) taking into account all the environmental variables, but when only the chemical characteristics of waters and sediments were considered, dif- 
Table 2. PCA of environmental data gathered at the time of seasonal biomass maximum at 27 sites in three different temporary salt marsh habitats in Doñana National Park. Correlations between environmental variables and the five extracted significant PCA factors are shown. $1=$ Salinity; $2=\mathrm{Ca}$ acidity; $3=$ Nutrients; $4=$ Wdepth; $5=$ TSP. Percentage variance accounted for by each axis is also given.

\begin{tabular}{lcrrrr}
\hline PCA factor & 1 & 2 & 3 & 4 & 5 \\
\hline $\mathrm{EC}$ & 0.92 & & & & \\
$\mathrm{Cl}^{-}$ & 0.90 & & & & \\
$\mathrm{SO}_{4}^{-}$ & 0.73 & & & & \\
$\mathrm{Na}^{+}$ & 0.87 & & & & \\
$\mathrm{~K}^{+}$ & 0.84 & & & & \\
$\mathrm{Mg}^{++}$ & 0.92 & & & & \\
$\mathrm{Ca}^{++}$ & & 0.72 & & & \\
$\mathrm{pH}^{-}$ & & -0.63 & & & \\
$\mathrm{CO}_{3}^{-}$ & & -0.87 & & & \\
$\mathrm{HCO}$ & & -0.85 & & & \\
$\mathrm{SOM}$ & & & 0.60 & & \\
$\mathrm{STN}$ & & & 0.66 & & \\
$\mathrm{NO}$ & & & 0.73 & & \\
$\mathrm{PO}_{4}^{-3}$ & & & 0.65 & & \\
$\mathrm{Chlorophyle} \mathrm{a}$ & & & 0.71 & & \\
Disk & & & & 0.95 & \\
Water Depth & & & & & 0.90 \\
STP & 31.1 & 17.5 & 15.5 & 11.8 & 6.7 \\
\% variance & & & & &
\end{tabular}

ferences between the Scirpus community and the other two habitats were significant $(P<0.001$ in the two comparisons), but not those between ArthrocnemumJuncus community and bare soil $(P=0.59)$.

Table 3 shows the mean values and the standard error of 19 environmental variables (including total alkalinity) measured at the 27 stations. For most of the variables, the significance of the differences between the three habitats studied is below the significance level fixed $(P<0.05)$, although only five of them (flooding period, $\mathrm{SOM}, \mathrm{NO}_{3}{ }^{-}$, alkalinity and $\mathrm{K}^{+}$) presented values of $P$ lower than required after application of the sequential Bonferroni correction. The post hoc univariate comparisons shown in Table 3 (when the significance of the ANOVA was below 0.05) lead to the same conclusion as with the multivariate test: most of the significant differences between the mean values of the environmental variables are between the Scirpus community and the other two habitats. Except for the duration of the flooding period, there are no significant differences between bare soil and Arthrocnemum-Juncus community. The difference in mean duration of flooding period between bare soil and Scirpus community (two weeks) was very near the significance limit $(P=0.04)$ and, in fact, other post hoc tests (as the unequal-N Tukey test) gave non-significant differences for flooding period $(P$ $=0.12$ ) between these two habitats.

When differences in the five PCA factors extracted from the SBM environmental set were considered (Table 4), only the factor Nutrients had significantly differ-
Table 3. Means and standard errors for 19 environmental variables (including alkalinity $=\mathrm{CO}_{3}^{-}+\mathrm{HCO}_{3}^{-}$) measured at 27 stations in three different habitats in temporary salt marshes at Doñana National Park, at the time of the seasonal biomass maximum. Data of flooding period for each habitat are also shown. Significance of between-habitat post hoc comparisons is indicated with letters. Only ANOVA P's which were significant after applying the sequential Bonferroni correction were considered for multiple comparisons. Difference in average flooding period between the wettest habitats was very near the signification limit and was not significant after applying other post hoc tests.

\begin{tabular}{|c|c|c|c|}
\hline & \multicolumn{3}{|c|}{ Community } \\
\hline & Bare soil & Scirpus & $\begin{array}{l}\text { Arthrocnemum } \\
\text {-Juncus }\end{array}$ \\
\hline Flooding period (wk) & $25^{\mathrm{a}(\mathrm{b})} \pm 0.6$ & $27^{\mathrm{b}} \pm 0.3$ & $21 \mathrm{c} \pm 0.5$ \\
\hline Secchi disk (m) & $0.25 \mathrm{a} \pm 0.01$ & $0.17 \mathrm{a} \pm 0.03$ & $0.15^{\mathrm{a}} \pm 0.03$ \\
\hline Water depth (m) & $0.26 a \pm 0.01$ & $0.25^{\mathrm{a}} \pm 0.03$ & $0.16 a \pm 0.03$ \\
\hline $\mathrm{NO}_{3}^{-}(\mathrm{mg}-\mathrm{at} \mathrm{N} / \mathrm{l})$ & $14.1 \mathrm{a} \pm 1.9$ & $23.3 \mathrm{~b} \pm 0.8$ & $16.5^{\mathrm{a}} \pm 1.8$ \\
\hline $\mathrm{PO}_{4}^{-}(\mathrm{mg}$-at $\mathrm{P} / \mathrm{l})$ & $0.3 \mathrm{a} \pm 0$ & $10.7 \mathrm{a} \pm 0.2$ & $0.4 \mathrm{a} \pm 0.1$ \\
\hline $\mathrm{HCO}_{3}^{-}(\mathrm{mmolc} / \mathrm{l})$ & $2.1 \mathrm{a} \pm 0.8$ & $4.0 \mathrm{a} \pm 0.4$ & $1.6 \mathrm{a} \pm 0.5$ \\
\hline $\mathrm{CO}_{3}^{-}(\mathrm{mmolc} / \mathrm{l})$ & $1.3 \mathrm{a} \pm 0.3$ & $0.8 \mathrm{a} \pm 0.2$ & $1.2 \mathrm{a} \pm 0.2$ \\
\hline Alkalinity (mmolc /l) & $3.4 \mathrm{a} \pm 0.6$ & $4.8 b \pm 0.3$ & $2.8 \mathrm{a} \pm 0.4$ \\
\hline $\mathrm{pH}$ & $9.3 a \pm 0.4$ & $8.5 a \pm 0.2$ & $10.1 \mathrm{a} \pm 0.4$ \\
\hline $\mathrm{EC}(\mathrm{dS} / \mathrm{m})$ & $4.3 \mathrm{a} \pm 0.4$ & $3.1 \mathrm{a} \pm 0.3$ & $4.4 \mathrm{a} \pm 0.4$ \\
\hline $\mathrm{Cl}-(\mathrm{mmolc} / \mathrm{l})$ & $37.0 \mathrm{a} \pm 3.6$ & $26.1 \mathrm{a} \pm 2.4$ & $40.4 \mathrm{a} \pm 4.8$ \\
\hline $\mathrm{Na}^{+}(\mathrm{mmolc} / \mathrm{l})$ & $44.7 \mathrm{a} \pm 4.7$ & $26.9 \mathrm{a} \pm 3.6$ & $42.9 \mathrm{a} \pm 4.3$ \\
\hline $\mathrm{K}^{+}($mmolc $/ \mathrm{l})$ & $0.9 \mathrm{a} \pm 0.06$ & $0.5 b \pm 0.04$ & $0.8 \mathrm{a} \pm 0.1$ \\
\hline $\mathrm{Ca}^{++}($mmolc $/ \mathrm{l})$ & $2.5 \mathrm{a} \pm 0.3$ & $3.5 \mathrm{a} \pm 0.2$ & $2.9 \mathrm{a} \pm 0.3$ \\
\hline $\mathrm{SO}_{4}^{-}(\mathrm{mmolc} / \mathrm{l})$ & $2.8 \mathrm{a} \pm 0.3$ & $2.5 \mathrm{a} \pm 0.2$ & $2.8 \mathrm{a} \pm 0.5$ \\
\hline $\mathrm{Mg}^{++}($mmolc $/ 1)$ & $7.2 \mathrm{a} \pm 0.7$ & $5.1 \mathrm{a} \pm 0.4$ & $7.1 \mathrm{a} \pm 0.6$ \\
\hline Chlorophyll-a (m g/l) & $6.1 \mathrm{a} \pm 2.6$ & $32.3 \mathrm{a} \pm 8.2$ & $27.8 \mathrm{a} \pm 13.3$ \\
\hline $\operatorname{SOM}(\%)$ & $7.4 \mathrm{a} \pm 1.3$ & $11.7 \mathrm{~b} \pm 0.7$ & $8.1 \mathrm{a} \pm 0.5$ \\
\hline STP (mg-at P/Kg) & $776 a \pm 66$ & $674 a \pm 26$ & $806 \mathrm{a} \pm 20$ \\
\hline STN (mg-at P/Kg) & $109 a \pm 40$ & $251 \mathrm{a} \pm 73$ & $118 \mathrm{a} \pm 21$ \\
\hline
\end{tabular}

ent scores $(P<0.001)$ in the three habitats studied. Between-habitat paired post hoc comparisons for this factor showed highly significant differences between the Scirpus community and bare soil $(P<0.006)$, only significant differences $(P<0.025)$ between the Scirpus and Arthrocnemum-Juncus communities, and no significant differences between the Arthrocnemum-Juncus community and bare soil $(P<0.12)$.

Table 4. Comparison of the scores for the environmental factors defined in Table 2 for the three habitats ('communities') studied. Mean values, standard errors, and significance of the differences (indicated by different letters) are shown. All factors, except nutrients, showed no significant differences between habitats.

\begin{tabular}{lrrr}
\hline Bare soil & \multicolumn{1}{c}{$\begin{array}{c}\text { Community } \\
\text { Scirpus }\end{array}$} & $\begin{array}{c}\text { Arthrocnemum } \\
\text {-Juncus }\end{array}$ \\
\hline Salinity & $0.07^{\mathrm{a}} \pm 0.36$ & $-0.62^{\mathrm{a}} \pm 0.26$ & $0.35^{\mathrm{a}} \pm 0.30$ \\
Ca-acidity & $-0.17^{\mathrm{a}} \pm 0.51$ & $0.31^{\mathrm{a}} \pm 0.24$ & $-0.11^{\mathrm{a}} \pm 0.30$ \\
Nutrients & $-0.84^{\mathrm{a}} \pm 0.29$ & $0.90^{\mathrm{b}} \pm 0.26$ & $-0.17^{\mathrm{a}} \pm 0.23$ \\
Wdepth & $0.81^{\mathrm{a}} \pm 0.12$ & $0.09^{\mathrm{a}} \pm 0.24$ & $-0.43^{\mathrm{a}} \pm 0.32$ \\
FSTP & $0.19^{\mathrm{a}} \pm 0.58$ & $-0.52^{\mathrm{a}} \pm 0.32$ & $0.23^{\mathrm{a}} \pm 0.22$ \\
\hline
\end{tabular}




\section{Distribution of helophytes}

Table 5 shows the average cover of perennials in the submerged macrophyte sampled sites for the three studied habitats. Fig. 1 shows the relationships between the previously defined environmental factors (Table 2) and the canonical axes maximizing the species-environment relationship according to a linear model (RDA). The bi-axial model $(P<0.001$, Monte Carlo test) explained around $60 \%$ of the total variance of the perennial species.

The first RDA axis (40\% explained variance, canonical correlation 0.95 ) represents the dominant gradient of flooding (FloodT; $P<10^{-4}$; Wdepth; $P=0.04$ ) and salinity (Salinity; $P<0.02)$, significantly $(P<0.005$ in all cases) correlated with the abundance of the Scirpus species (positively) and (negatively) with Arthrocnemun and Juncus. The second RDA axis represents a gradient of oligotrophy (associated to a lesser availability of nutrients, calcium, and bicarbonate), negatively correlated with the factor Nutrients $(P<0.0002)$, and, more weakly, with the factor Ca-acidity $(P<0.02)$. After the use of a forward stepwise procedure, only FloodT and Nutrients contributed significant independent information to the model. The other factors were redundant (Salinity, Wdepth and Ca-acidity) or did not present any relationship with the ordination axes (STP).

Of the perennial species studied, only the combined abundance of emergent helophytes (S. maritimus and $S$. litoralis; Fig. 1) was significantly correlated with the factor Nutrients $(P<0.002)$. Scirpus abundance was positively correlated with sediment OM $(P$ $<0.001)$ and $\mathrm{N}(P<0.003)$ and to water nitrate $(P<$ 4.1.10 $\left.0^{-5}\right)$, Chl-a $(P<0.003)$, acidity $(P<0.0005)$, bicarbonate $(P<0.0003)$, and relative $\mathrm{Ca}$ (to $\mathrm{Na}$ and $\left.\mathrm{Mg}, P<5.10^{-6}\right)$ levels. In contrast, the combined abundance of the two Scirpus species was negatively correlated with sediment total $P$ level $(P<0.003)$.

Table 5. Distribution of perennials in the three studied communities. Mean cover and standard errors are shown. Significant differences are indicated with different letters.

\begin{tabular}{|c|c|c|c|}
\hline & Bare soil & Scirpus & Arthr.-Juncus \\
\hline Arthrocnemum macrostachyum & $0^{\mathrm{a}} \pm 0$ & $0^{\mathrm{a}} \pm 0$ & $39^{b} \pm 3$ \\
\hline Juncus subulatus & $0^{\mathrm{a}} \pm 0$ & $0^{\mathrm{a}} \pm 0$ & $24^{\mathrm{b}} \pm 3$ \\
\hline Scirpus maritimus & $0^{\mathrm{a}} \pm 0$ & $49^{b} \pm 14$ & $4^{\mathrm{a}} \pm 0$ \\
\hline Scirpus litoralis & $0^{\mathrm{a}} \pm 0$ & $31^{\mathrm{b}} \pm 13$ & $0^{\mathrm{a}} \pm 0$ \\
\hline Bare soil & $100^{\mathrm{a}} \pm 0$ & $20^{\mathrm{b}} \pm 4$ & $32^{\mathrm{b}} \pm 4$ \\
\hline
\end{tabular}

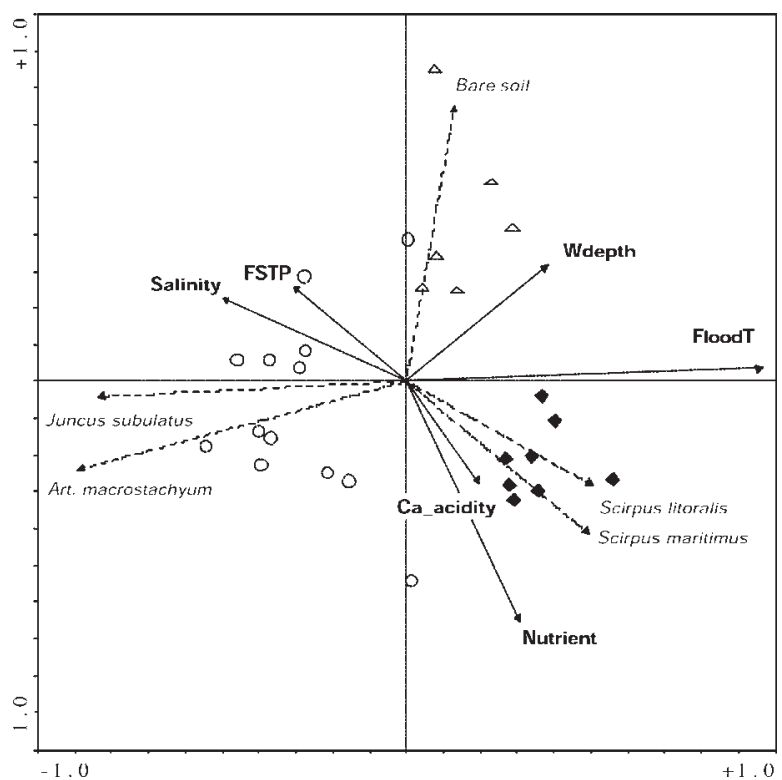

Fig. 1. Relationships between relative abundance of perennials and environmental factors derived from measurements at the seasonal biomass maximum of submerged macrophyte communities (Salinity, Ca-acidity, Nutrients, Wdepth and FSTP, see Table 2), and total flooding period (FloodT) for each site. Sites at different habitats are indicated by symbols ( $\triangle$ = bare areas; $\$$ = Scirpus community; $\bigcirc=$ ArthrocnemumJuncus community). Ordination axes have been obtained by redundancy analysis (RDA) and tested by a Monte Carlo permutation test.

Table 6. Means and standard error of the biomass values $\left(\mathrm{g}-\mathrm{DW} \cdot \mathrm{m}^{-2}\right)$ for ten submerged macrophyte species, measured at the time of the seasonal biomass maximum 1996-1997, for the three 'communities': 'Bare soil' in early May $(n=8)$, 'Scirpus community' in early May $(n=6)$, and 'ArthrocnemumJuncus community' in April $(n=13)$. The values of biomass recorded in the three communities were compared using the Kruskal-Wallis test, and when significant, pairwise MannWhitney tests were applied. The values of $P$ which were found significant following the application of the Bonferroni sequential correction to between habitat-comparisons are indicated with different letters.

\begin{tabular}{lcrr}
\hline & \multicolumn{3}{c}{ Biomass $\left(\mathrm{g} \mathrm{DW} / \mathrm{m}^{2}\right)$} \\
& Bare soil & Scirpus & Arthr. -Junc. \\
\hline Charophytes & & & \\
Chara galioides & $35.1 \mathrm{a} \pm 21.7$ & $0.0 \mathrm{~b} \pm 0.0$ & $37.9 \mathrm{a} \pm 7.8$ \\
Chara aspera & $4.71 \mathrm{a} \pm 4.7$ & $5.7 \mathrm{a} \pm 5.7$ & $0.0 \mathrm{a} \pm 0.0$ \\
Chara canescens & $42.1 \mathrm{a} \pm 23.5$ & $4.3 \mathrm{~b} \pm 4.3$ & $24.1 \mathrm{a} \pm 16.9$ \\
Chara connivens & $18.8 \mathrm{a} \pm 9.7$ & $67.3 \mathrm{a} \pm 33.7$ & $0.0 \mathrm{~b} \pm 0.0$ \\
Nitella hyalina & $14.2 \mathrm{a} \pm 14.0$ & $30.8 \mathrm{a} \pm 18.1$ & $0.05 \mathrm{~b} \pm 0.03$ \\
C. canescens + C. galioides $)$ & $77.2 \mathrm{a} \pm 26.0$ & $4.30 \mathrm{~b} \pm 4.3$ & $62.1 \mathrm{a} \pm 15.5$ \\
Spermatophytes & & & \\
Ranunculus peltatus & $0.00 \mathrm{a} \pm 0.00$ & $0.00 \mathrm{a} \pm 0.00$ & $0.02 \mathrm{a} \pm 0.02$ \\
Damasomium alisma & $1.22 \mathrm{a} \pm 1.23$ & $0.00 \mathrm{a} \pm 0.00$ & $0.01 \mathrm{a} \pm 0.01$ \\
Callitriche truncata & $0.16 \mathrm{a} \pm 0.09$ & $0.00 \mathrm{a} \pm 0.00$ & $1.86 \mathrm{a} \pm 0.90$ \\
Ruppia drepanensis & $0.09 \mathrm{a} \pm 0.09$ & $0.00 \mathrm{a} \pm 0.00$ & $0.00 \mathrm{a} \pm 0.00$ \\
Zannichellia obtusifolia & $0.02 \mathrm{a} \pm 0.02$ & $0.00 \mathrm{a} \pm 0.00$ & $0.53 \mathrm{a} \pm 0.53$ \\
Total biomass & $116.3 \mathrm{a} \pm 24.3$ & $108.1 \mathrm{a} \pm 29.8$ & $64.5 \mathrm{a} \pm 15.1$ \\
\hline
\end{tabular}




\section{Submerged macrophyte distribution}

During the study period, ten different species of submerged aquatic macrophytes were collected (Table 6). The MRPP test detected highly significant $\left(P=2.10^{-5}\right)$ multivariate differences in the distribution of the set of submerged macrophyte species for the three habitats. The most significant differences were between the Scirpus community and the Arthrocnemum-Juncus community $\left(P=7.10^{-6}\right)$ and between bare soil and the Scirpus community $(P=0.02)$, while no significant $(P=$ $0.05)$ difference was found between bare soil and the Arthrocnemum-Juncus community.

The differences in abundance of the spermatophyte species set in the three habitats studied were not significant, due to their scarce presence in all of them, while those of three charophyte species (Chara galioides, $C$. connivens and Nitella hyalina) were highly significant (Table 6).

Post hoc comparisons between community pairs (Table 6) showed that Chara connivens and Nitella hyalina significantly dominated in the lower zones together with Scirpus spp., while the Arthrocnemum-

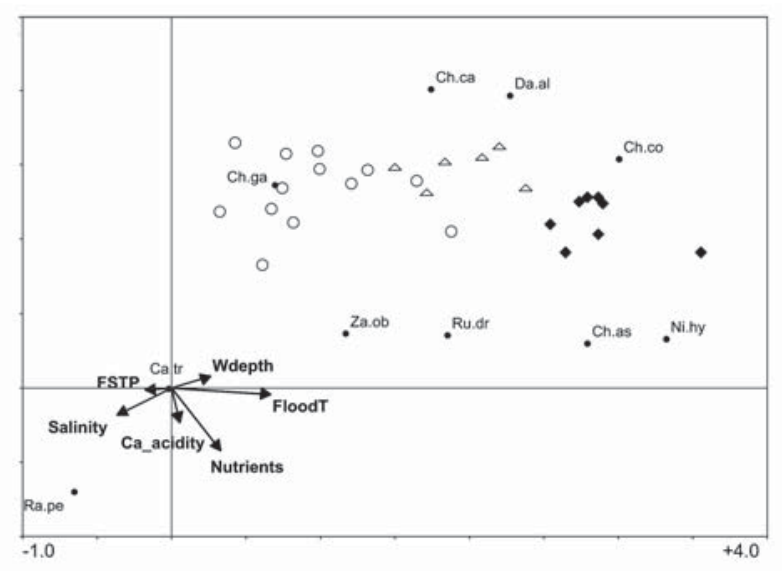

Fig. 2. Direct gradient analysis. Joint plot of species of submerged macrophytes, sites, and environmental factors in the ordination plane defined by the two first DCCA axes. Environmental variable set includes (1) environmental factors derived from measurements at the seasonal biomass maximum (Salinity, Ca-acidity, Nutrients, Wdepth and FSTP, see Table 2), and (1) total flooding period (FloodT). Sites at different habitats are indicated by symbols: $\triangle=$ bare areas; $\bullet=$ Scirpus community; $\bigcirc=$ Arthrocnemum-Juncus community. Submerged macrophyte species abbreviations: $\mathrm{Ch}$ as = Chara aspera $; \mathrm{Ch}$ ga $=$ Chara galioides $; \mathrm{Ch}$ co $=$ Chara connivens; Ch ca $=$ Chara canescens $;$ Ny hy $=$ Nitella hyalina $;$ Ra pe $=$ Ranunculus peltatus ssp. fucoides; $\mathrm{Da}$ al = Damasonium alisma; $\mathrm{Ca} \operatorname{tr}=$ Callitriche truncata ssp. occidentalis; $\mathrm{Ru} \mathrm{dr}=$ Ruppia drepanensis; $\mathrm{Za} \mathrm{ob}=$ Zannichellia obtusifolia .
Juncus community was virtually absent. In contrast, Chara galioides showed a biomass distribution clearly complementary to that of the two above-mentioned charophyte species, dominating in the habitats where Scirpus was absent. The distribution of biomass values for Chara canescens was similar to that for Chara galioides, although values for bare soil were higher. The joint biomass distribution of $C$. galioides and $C$. canescens shows a significant differential distribution (Table 6, in brackets), clearly complementary to that of C. connivens and N. hyalina.

\section{Submerged macrophyte-environment relationships}

Application of a stepwise CCA procedure to macrophyte abundance and environmental data sets yielded a highly significant $(P<0.0005 ; 104$ Monte Carlo permutations) biaxial model, explaining ca. $30 \%$ of the total variance in macrophyte abundance. Only two environmental factors (FloodT and Nutrients) were selected as significant predictors. However, the CCA diagram showed a strong distortion of the main gradient (an 'arch'), which made interpretation of the second ordination axis difficult. Segment-detrendedDCCA analysis (ter Braak \& Šmilauer 1998) greatly improved the interpretation of the underlying environmental gradients (Table 7). Both first axis and matrix trace were highly significant $(P<0.005$, in both cases) after 104 Monte Carlo permutations. A main gradient of flooding period-salinity (accounting for $23.7 \%$ of total species variance) and a secondary gradient of (decreasing) nutrient availability (accounting for $4.4 \%$ of the total variance) emerged as the environmental factors most closely related to the measured changes in the submerged macrophyte abundances.

As to the originally measured environmental variables, the first DCCA axis was significantly $(P<0.001)$ positively correlated to flooding period and total alkalinity, and negatively to $\mathrm{K}, \mathrm{EC}$, and $\mathrm{pH}$, while the

Table 7. Results from DCCA analysis of macrophyte abundance data and six environmental factors (flooding period, salinity, Ca-acidity, water depth and transparency, and soil total phosphorus). Only correlations that were significant at the $P=0.005$ level are shown.

\begin{tabular}{lcc}
\hline & DCCA Axis 1 & DCCA Axis 2 \\
\hline Eigenvalues & 0.63 & 0.12 \\
\% Variance (cumulative) & 23.7 & 28.1 \\
S/E correlations & 0.90 & 0.55 \\
Correlations with environmental factors & \\
FloodT & 0.94 & - \\
Nutrients & - & -0.83 \\
Salinity & -0.53 & - \\
\hline
\end{tabular}



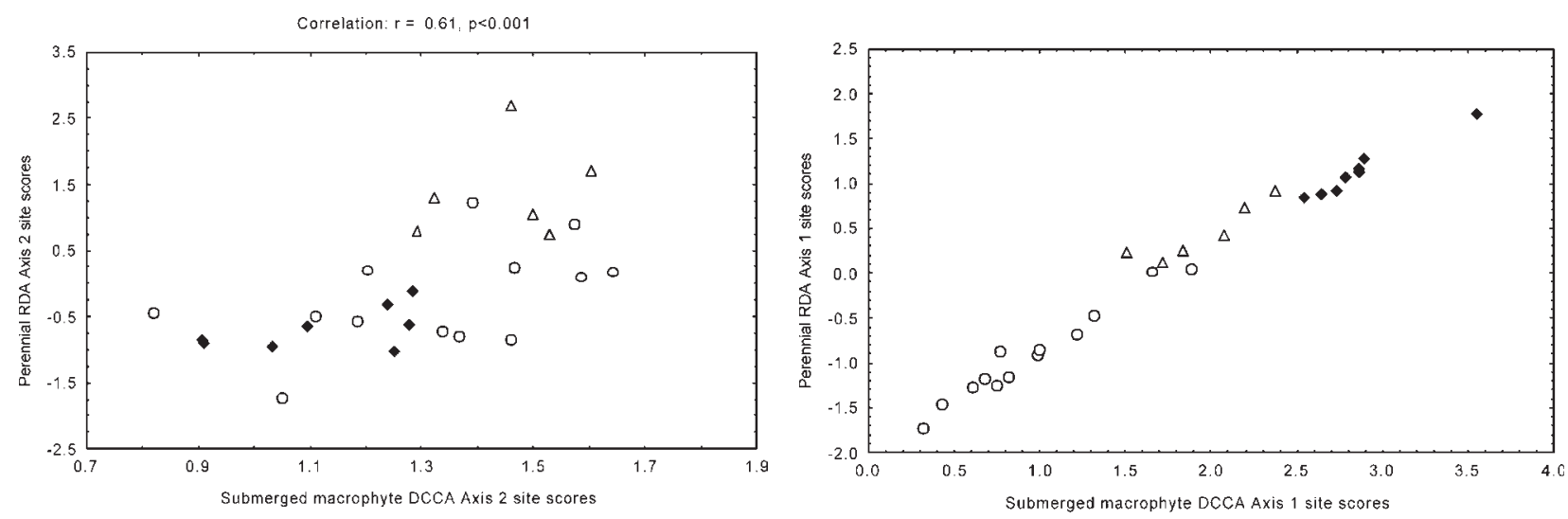

Fig. 3. Relationships between (canonical) ordination axes derived from RDA (environment; abundance of emergent perennials) and DCCA (environment; submerged macrophyte biomass). Significance of correlations between axes, and symbols for the three different habitats analysed; $\triangle$ = bare soil, $\diamond=$ Scirpus community, $\bigcirc=$ Arthrocnemum-Juncus community, are also shown.

second DCCA axis was correlated negatively $(P<0.001)$ to nitrate, phosphate, $\mathrm{Ca}$, and $\mathrm{Chl}-\mathrm{a}$ concentrations in the water column (Table 6).

As to the position of well-represented species (occurring in at least $30 \%$ of the stations) in relation with the three environmental factors significantly related with the ordination axes (FloodT, Salinity and Nutrients, Fig. 2), we note: 1. Chara connivens and Nitella hyalina reach their optimum in the habitats least saline and most flooded, although Nitella prefers more eutrophicated stations (Scirpus community). 2. Chara canescens and C. galioides successively occupy zones less prone to flooding and more oligotrophic than the former two species; they occur preferentially on Bare soils $(C$. canescens) and Arthrocnemum-Juncus community (C. galioides). 3. Callitriche truncata ssp. occidentalis, the only spermatophyte well represented in the study, occupies stations more shallow and saline than the charophytes mentioned, although with an intermediate degree of eutrophy. This interpretation is in accordance with the differences found in the inter-habitat comparisons (Tables 3 and 6).

The structure based on the relation between submerged macrophytes and environmental variables (Fig. 2) is very similar to that between emergent perennials and environmental variables (Fig. 1). In fact, the two first axes derived from each analysis are linearly related in a highly significant way (Fig. 3). The relative abundance of all emergent perennials showed a highly (positive or negative) significant correlation $(P<0.001)$ with the scores of the first submerged macrophyte DCCA axis, but only the combined abundance of Scirpus species was significantly $(P<0.008)$ related to the second DCCA axis scores, derived from the submerged macrophyte abundance-environment analysis (Fig. 3).
From Fig. 2 it is deduced, furthermore, that the response of the two environmental factors considered is not uniform within the groups of submerged macrophytes dominant in each habitat: $C$. connivens- $N$. hyalina appear to have a similar optimum period of flooding, but the optimum nutrient level is much higher for $N$. hyalina. In contrast, the projection on the Nutrients vector (Fig. 2 ) is similar for C. canescens and C. galioides, which, however, show separate optima on the gradient of flooding. The higher tolerance of the latter two species to changes in the period of flooding and in the nutrient levels means that their overall production is some $50 \%$ higher (in the set of the 27 plots sampled) than that of $C$. connivens- $N$. hyalina, despite the apparently greater productivity of the latter (Table 6).

\section{Discussion}

Relationship between established helophytes and the physico-chemical environment

The multivariate and univariate contrasts obtained demonstrate the existence of significant differences between the three communities studied, both in environmental characteristics and in the distribution of the submerged macrophytes (Tables 3 and 6). The most significant differences are between sites with different perennial cover rather than between sites with morecontrasted periods of flooding.

Part of the environmental differences detected (e.g. sediment organic matter and water nitrate levels) are directly related to helophyte abundance. The concentrations of limiting essential nutrients (nitrates and orthophosphates) and of chlorophyll-a in the water column 
tend to change together with the content of organic matter and total nitrogen in the sediment, and all of these are related positively and significantly to the abundance of Scirpus (Fig. 1).

In contrast, the relationship is negative with regard to P-content in the sediment. Boon \& Sorrell (1991) obtained a similar result when comparing areas colonized by helophytes with bare areas, in permanent floodplain lakes. The increase in levels of soluble $\mathrm{P}$ in the water column, parallel to the decrease in P-stock of the sediment, associated with the increase in relative abundance of Scirpus, indicates a process of mobilization of sediment $\mathrm{P}$, parallel to the reduction of carbonates in the first $\mathrm{cm}$ of soil found by Clemente et al. (1998) under dense populations of Scirpus. This putting into circulation of $\mathrm{P}$ previously trapped in the sediment means that the helophytes can behave as a 'phosphate pump' (Boström et al. 1980; Granéli \& Solander 1988), causing an increase in P-concentration in waters normally very poor in this nutrient. The immediate effect of this fertilization would be a proliferation of phytoplankton in the environment which is consistent with the significant increase in chlorophyll-a levels in the water column observed in the study zone.

The nutrients retained in the biomass of Scirpus and those immobilized in the sediment pass into the water column by different processes (organic matter mineralization, liberation of nutrients in senescence, environmental oxygenation, and liberation of sediment phosphorus, due to physico-chemical changes in the environment of the rhizomes) that have been amply discussed by several authors (Boström et al. 1980; Granéli \& Solander 1988; Golterman 1995). Clemente et al. (1998) have shown, in the same study zone, that the soils developing below dense communities of helophytes present notable differences in their surface physical and chemical characteristics. Comparing zones with similar flooding regime and substrate (to $20 \mathrm{~cm}$ depth), they observed that as the abundance of helophytes of the genus Scirpus increased, there was an increase in the contents of $\mathrm{OM}$ and $\mathrm{N}$, accompanied by a decrease in the stock of calcium carbonate precipitated in the soil. The immediate consequence of carbonate reduction in the sediment is the liberation of $\mathrm{Ca}^{++}$to the column, preventing an increase in the $\mathrm{pH}$ values (Table 3 ), factors that in turn determine the solubility of the phosphorus bound to sediment iron (Golterman 1995).

The significant decrease in the levels of $\mathrm{K}^{+}$in the water column in the areas colonized by Scirpus (Table 3) may be related with the trend towards accumulation of this nutrient observed in species of the genus Scirpus, reaching almost $1 \%$ of the dry weight of the shoot at SBM in S. litoralis (Ennabili et al. 1998).

\section{Submerged macrophytes and environmental gradients}

Direct analysis of gradients has enabled the detection of two significant trends of variation in the composition of the communities of submerged aquatic macrophytes. These trends are significantly associated with gradients of resource availability (water and nutrients) and, more weakly, with transparency and salinity of the water column. Earlier studies of similar ecosystems have established that the flooding period is the environmental variable that best explains macrophyte distribution (Grillas 1990; Grillas et al. 1993a). However, our analysis reveals a second factor, related exclusively with nutrient availability, firmly associated with the distribution and productivity of certain species of submerged macrophytes.

The effects of the liberation of limiting essential nutrients in a nutrient-poor medium (such as the studied marsh) are well known (Tilman 1993; Tilman \& Pacala 1993): the dominance of species that are very productive and with high requirements of nutrients ("nutrient demanders') is favoured, and there is, in most cases, a reduction in the number of species present.

The differences of salinity found between the ends of the gradient $\left(3 \mathrm{dS} . \mathrm{m}^{-1}\right)$ are within the known tolerance ranges for most of the species (Grillas 1990; Martinez-Taberner \& Moyá 1993; Grillas et al. 1993a), and are scarcely significant to explain the variations found in the composition of the submerged macrophyte communities. In fact, the variations in salinity found are related with the persistence of flooding and with the first ordination axis of the submerged macrophyte communities, suggesting that in the wet hydrological cycle studied - with an extensive, relatively little-segmented water sheet - the salinity of the water column is strongly linked to its persistence. However, other research carried out in zones similar to the ones under study shows that the salinity of the water column can determine, by itself, the species distribution and the seasonal biomass production (Grillas et al. 1993b), which is directly related with the production of seeds and oöspores (Bonis et al. 1993). The sustained changes of salinity gradually alter the composition of the communities, via an accumulative effect in the composition of the seed bank. In such a highly dynamic environment, the community composition is the result of a balance between the current environmental conditions and the historical processes involved in establishing the species (Seabloom et al. 2001).

In the set of habitats studied, the levels of calcium (relative to sodium and magnesium) are low and closely related with the $\mathrm{pH}$ values of the water column and with the concentrations of the chemical species involved in the equilibria in the carbon-bicarbonates- 
carbonates system. In salt marshes, the water column $\mathrm{pH}$ reaches $10-11$ in situations of high photosynthetic activity, causing the displacement of the dissolved carbon towards the formation of carbonates. The minimum values of $\mathrm{pH}$ and dissolved carbonates, and the greater relative availability of calcium, found at the Scirpus community suggest that, despite the high density of the submerged macrophyte communities and of phytoplankton in this habitat, the greater relative concentration of calcium prevents the extreme displacement of the equilibria towards carbonates (Wetzel 1981), buffering the increase in $\mathrm{pH}$ of the waters and maintaining a high availability of bicarbonates, even in situations of high photosynthetic rates. Although in the data analysis the relevance of the factor Ca-acidity has been secondary in explaining the macrophyte species distribution, the differences found in the predomination of the various forms of dissolved carbon can be relevant in the nutrition of the submerged macrophytes, favouring species that most efficiently use bicarbonate as carbon source (Sand-Jensen 1987).

We have found a highly significant $(P<0.001)$ linear relationship between the abundance of Nitella hyalina and the bicarbonate content of the water column.

\section{Facilitation may contribute to explain zonation}

The results of this work suggest that the emergent helophytes of the genus Scirpus play an essential role in the generation of secondary sources of environmental variability that, superimposed on the principal gradient of flooding-salinity, increase the variability of the characteristics of the water and sediment, favouring the appearance of new equilibria in the communities of submerged aquatic macrophytes.

We have described what may be a process of facilitation in which the positive interaction results from an environmental alteration (induced by the emergent helophytes) that favours the beneficiary species (mainly Chara connivens and Nitella hyalina) with respect to other submerged species (mainly $C$. canescens and $C$. galioides), which dominate in the absence of the benefactor species. As far as we know, it would be the first example of chemical facilitation of submerged annual communities by emergent perennial communities in temporary marshes.

Acknowledgements. We thank Laura Serrano and Teodoro Marañón for their critical review of the manuscript, and Luis Clemente for the facilities provided for the preparation of this work. Financial support from the Junta de Andalucía (research group \#4086 and \#RNM 123) and from MMA (project 05/99) and CICYT (AMB95-1054) has enabled us to carry out the present work.

\section{References}

Anon. 1985. Standard methods for the examination of water and wastewater. 16th ed. APHA, AWWA, WPCF, Washington, DC.

Bertness, M.D. \& Callaway, R. 1994. Positive interactions in communities. Trends Ecol. Evol. 9: 191-193.

Bonis, A., Grillas, P., van Wijck, C. \& Lepart, J. 1993. The effect of salinity on the reproduction of coastal submerged macrophytes in experimental communities. J. Veg. Sci.4: 461-468.

Boström, B.J.M. \& Forsberg, C. 1882. Phosphorus release from lake sediments. Arch. Hydrobiol. Beih. Ergebn. Limnol. 18: 5-59.

Callaway, R.M. 1994. Facilitative and interfering effects of Arthrocnemum subterminale on winter annuals. Ecology 75: 681-686.

Callaway, R.M. \& Walker, L.R. 1997. Competition and facilitation: a synthetic approach to interactions in plant communities. Ecology 78: 1958-1965.

Carpenter, S.R. \& Lodge, D.M. 1986. Effects of submersed macrophytes on ecosystem processes. Aquat. Bot. 26: 341-370.

Chambers, J.C. 2001. Pinus monophylla establishment in an expanding Pinus-Juniperus woodland: Environmental conditions, facilitation and interacting factors. J. Veg. Sci. 12: $27-40$.

Chen, R.L. \& Barko J.W. 1988. Effects of freshwater macrophytes on sediment chemistry. J.Freshwater Ecol.4:279289.

Clemente, L., García, L.V. \& Siljestrom, P. 1998. Los suelos del Parque Nacional de Doñana. Ministerio de Medio Ambiente, Madrid, ES.

Corillion, R. 1961. Les végétation précoces de Charophycées d'Espagne Méridionale et du Maroc Occidentale. Rev. Gén. Bot. 804: 317-331.

Ennabili, A., Ater, M. \& Radoux, M. 1998. Biomass production and NPK retention in macrophytes from wetlands of the Tingitan peninsula. Aquat. Bot. 62: 45-56.

Espinar, J.L., Garcia Murillo, P. \& Cirujano, S. 1997. Contribución al conocimiento de los carófitos del P.N. de Doñana. Acta Bot. Mal. 22: 209-211.

García, L.V., Marañón, T., Moreno, A. \& Clemente, L. 1993. Above-ground biomass and species richness in a Mediterranean salt marsh. J. Veg. Sci. 4: 417-424.

García-Murillo, P., Bernués, M. \& Montes, C. 1990 Los macrofitos acuáticos del Parque Nacional de Doñana (SW España). Aspectos Florísticos. Actas VI Congreso Español de Limnología, pp. 261-267. Granada.

Granéli, W. \& Solander, D. 1988. Influence of aquatic macrophytes on phosphorus cycling in lakes. Hydrobiologia 170: 245-266.

Grillas, P. 1990. Distribution of submerged macrophytes in the Camargue in relation to environmental factors. J. Veg. Sci. 1: 339-402.

Grillas, P., Garcia Murillo, P., Geertz-Hansen, O., Marbá, N, Montes, C., Duarte, C., Tan Ham, L. \& Grossman, A. 1993a. Submerged macrophyte seed bank in a Mediterranean temporary marsh: abundance and relationship with 
established vegetation. Oecologia 94: 1-6.

Grillas, P., van Wijck, C. \& Bonis, A. 1993b. The effect of salinity on the dominance-diversity relations of experimental macrophyte communities. J. Veg. Sci. 4: 453-460.

Golterman, H.L.1995. The labyrinth of nutrient cycles and buffers in wetlands: results on research in the Camargue (southern France). Hydrobiologia 315: 39-58.

Holm, S. 1979. A simple sequential rejective multiple test procedure. Scand. J. Stat. 6: 65-70.

Huebert, D.B. \& Gorham, P.R. 1983. Biphasic mineral nutrition of the submerged macrophyte Potamogeton pectinatus. L. Aquat. Bot. 16: 269-284.

Jaynes, M.L. \& Carpenter, S.R. 1986. Effects of vascular and non-vascular macrophytes on sediment redox and solute dynamics. Ecology 67: 875-882.

Jongman, R.H.G., ter Braak, C.J.F. \& van Tongeren, O.F.R. 1997. Data analysis in community and landscape ecology. Cambridge University Press, Cambridge, UK.

Marañón, T. 1998. Soil seed bank and community dynamics in an annual-dominated Mediterranean salt-marsh. J. Veg. Sci. 9: 371-378.

Marañón, T., García, L.V., Murillo, J.M. \& Clemente, L. 1989. Las marismas del Guadalquivir: reserva biogenética de plantas tolerantes a la salinidad. Anal.Edafol. Agrobiol. 48: 725-740.

Martinez-Taberner, A. \& Moya, G. 1999. Submerged vascular plants and water chemistry in the coastal marsh Albufera de Mallorca (Balearic-Islands). Hydrobiologia 271: 129139.

Noe, G.B. \& Zedler, J.B. 2001. Spatio-temporal variation of salt marsh seedling establisment in relation to the abiotic and biotic environment. J. Veg. Sci. 12: 61-74.

Podlejski, V.D. 1981. Observations sur Scirpus maritimus en Camargue. Ecol. Medit. 7: 63-78.

Rivas Martinez, S., Costa, M., Castroviejo, S. \& Valdes, B.
1980. Vegetación de Doñana. (Huelva, España). Lazaroa 2: 5-190.

Rubio-Casal, A.E., Castillo, J.M., Luque, C.J. \& Figueroa, M.E. 2001. Nucleation and facilitation in salt pans in Mediterranean salt marshes. J. Veg. Sci. 12: 761-770.

Sand-Jensen, K. 1987. Environmental control of bicarbonate use among freshwater and marine macrophytes. In: Crawford, R.M.M. (ed.) Plant life in aquatic and amphibious habitats, pp. 99-112. Blackwell. Oxford, UK.

Seabloom, E.W., Moloney, K.A. \& van der Valk, A.G. 2001. Constraints on the establisment of plants along a fluctuating water-depth gradient. Ecology 82: 2216-2232.

ter Braak, C. \& Šmilauer, P. 1998. Canoco for Windows, $v$. 4.0. Center for Biometry Wageningen, Wageningen, NL.

Tilman, D. 1993. Species richness of experimental productivity gradients: how important is colonization limitation? Ecology 74: 2179-2191.

Tilman, D. \& Pacala, S. 1993. The maintenance of species richnnes in plant communities. In: Ricklefs, R.E. \& Schluter, E.D. (eds.) Species diversity in ecological communities. Historical and geographical perspectives, pp. 13-25. Chicago University Press, Chicago, IL.

Ungar, I.A. 1998. Are biotic factors significant in influencing the distribution of halophytes in saline habitats? Bot. Rev. 64: 176-179.

Valdes, B., Talavera, S. \& Fernández Galiano, E. 1987. Flora vascular de Andalucía Occidental. Ketres. Barcelona, ES.

van Vierssen, W. 1982. The ecology of communities dominated by Zannichellia taxa in Western Europe II. Distribution, synecology and productivity aspects in relation to environmental factors. Aquat. Bot. 13: 385-483.

Wetzel, G. 1981. Limnología. Omega, Barcelona, ES.

Zimmerman, G.M., Goetz, H. \& Mielke, PW. Jr. 1985. Use of an improved statistical method for group comparisons to study effects of prairie fire. Ecology 66: 606-611.

Received 18 December 2001;

Revision received 2002;

Accepted 23 August 2002.

Coordinating Editor: J.P. Bakker. 